\title{
Character Education Values in Animation Movie of Nussa and Rarra
}

\author{
Riskiana Widi Astuti ${ }^{1}$, Herman J Waluyo ${ }^{2}$, and Muhammad Rohmadi ${ }^{3}$ \\ ${ }^{1,2,3}$ University of Sebelas Maret, Central Java, Indonesia \\ riskianawidiastuti@student.uns.ac.id
}

\begin{abstract}
Character education value is needed in the education world. This study discussed a study of character education values through animation movie object of nussa and rarra, i.e. (1) religious character education value, (2) curiosity character education value, (3) friendly/communicative character education value, (4) social care character education value, (5) responsibility character education value. The researcher only limited five values of character education and used an animation movie object of nussa and rarra because the movie was trending in Indonesia. This study used survey methods and content analysis with qualitative research type because the data generated in the form of descriptions of speech fragments in the animation movie of nussa and rarra, then it divided into five types of utterances that contained the character education values and last, it analyzed. The result revealed that speech in an animation movie of nussa and rara, only five types of character education were found.
\end{abstract}

Keywords: Character education values; movie; animation movie.

\section{Introduction}

Education is an obligation of every human being that must be pursued to hold responsibilities and try to produce progress in knowledge and experience for the lives of every individual. Indonesia is a developing country that also prioritizes and tries to develop all aspects of the education world. This research focused on the study of character education values contained in the animation movie of nussa and rarra. Character education values can be said to be a program to form attitudes that connect or harmonize between culture, environment, and social.

Animation movie of nussa and rarra is appropriate to be used as objects of analysis using the character education values because the movie reveals positive things related to social, environmental, and cultural. Animation movie of nussa and rarra can be seen through the youtube channel produced by the little giatz. The researcher only focused on five values of character education, i.e. ((1) religious character education value, (2) curiosity character education value, (3) friendly/communicative character education value, (4) social care character education value, (5) responsibility character education value.

\section{Review of Literature}

Character education value is not only found in the process of learning with formal education but the environment also affects the formation of attitude or character. (Mansur, 2011) argued that education is the formation and character building of a good moral attitude. Meanwhile, (Munir, 2010) revealed that the character of the relationship between thought patterns, attitudes, and actions that have been inherent in a person and it becomes a characteristic of individuals. Character education is a matter of ethical concern and sympathy related to morals, (Noddings, 2002). In contrast to previous opinions, (Koellhoffer (2009)) argued that teaching character is learning to assess and instill good things and is an 
opportunity for young people to specify honesty and justice in the real world. Besides, (Tridhonanto, 2014) explained that character education is an effort designed and carried out systematically to help students or children understand the values of human behavior related to God, the environment, and social.

In a study conducted by (Cepi, 2015) entitled "The development of three-dimensional animation film for character education media in elementary school". A study conducted by Riyana used the Research \& Development (R\&D) method through the stages of media needs analysis, media development, product validation, and dissemination. The result of this study indicated that the animation model designed with $\mathrm{ABC}$ (animation character building) has a positive impact on habituation as the first step to character building for elementary students. Then, this study was a pragmatic study of the implicature, presuppositions, and values contained in the object, i.e. movie. Meanwhile, (Suhadi, 2018) also conducted a study on "Character education values in short stories written by Wisran Hadi". This study revealed the educational values contained in Waskat short stories. The data in this study were analyzed by reading and understanding and looking for educational values contained, in this short story, it found educational values such as religiosity, honesty, tolerance, discipline, accuracy, independence, communicative, love, peace, values, and social care. Besides, the study conducted by the researcher was the educational values contained in the animation movie of nussa and rara, however, the researcher only used three educational values, namely religious, social, and moral.

(Lickona, 2008) revealed that there are three components of good quality in character, those are" (1) moral knowledge, including: (a) moral awareness, (b) knowing moral values, (c) taking perspective, (d) moral reasoning, (e) decision making, and (f) self-knowledge. (2) moral feelings, including: (a) conscience, (b) self-esteem, (c) empathy, (d) liking kindness, (e) self-control, (f) humility, (3) moral actions, including: (a) competence, (b) willpower, and (c) habit. The three components have a relationship because the assessment and moral feelings will be seen to influence moral behavior. The opinion above has explained about education and character, the researcher can synthesize that character education is the effort of every individual in forming attitudes or behaviors towards each individual that aims to empower their own potential, culture and social environment.

Movie is a means of entertainment for everyone, as well as in this study, which makes animation movie as the object of study regarding the character education values. (Pikkov, 2010) explained that movie is animation because it is presented in certain forms such as puppet pictures in explaining the illusion of motion. Meanwhile, (Kenny Roy, 2014) explained that the characteristics of the animation movie should not be more than forty minutes because, in the movie, the main focus is in introducing the characteristics. Besides, (Bendazzi, 2018) expressed that the provisions in the animation movie, the language should be summarized naturally and must be continuous with artistic and rhythm, this activity is carried out by artists and craftsmen of small studio groups of their time. Therefore, the opinion about the movie, it can be concluded that animation movie is a movie flavored with editing to attract viewers' visibility. The context is also needed in this study because in analyzing the topic or theme of the conversation must be clear. 


\section{Discussion}

Character education values that contained in animation movie of nussa and rarra, the researcher has limited the five points of character education values, namely (1) religious character education value, (2) curiosity character education value, (3) friendly/communicative character education value, (4) social care character education value, (5) responsibility character education value. The following study analyzes the character education values in the movie of nussa and rarra:

\subsection{Religious Character Education Value}

(1) Context: Nussa Advises Rarra About the Manner Before Sleeping

Rarra : Oh, maybe.

Nussa : Therefore, if you want to sleep, firstly, you have to read bismillahhir rahmanir rahiim.. uh uh (while cleaning the bed using a broomstick).

Rarra : Alhamdulillah (Thank God), because I was tired of playing, I forgot to close the window.

\section{(Data 1)}

Fragment of speech discourse (1) on (Data 1) "Therefore, if you want to sleep, firstly, you have to read bismillahhir rahmanir rahiim.. uh uh (while cleaning the bed using a broomstick)" includes in the category of religious character education, in which the speech partner is taught or given a manner spiritual education that must be done before going to bed, it explains in the conversation starting from reading basamallah, cleaning the bed first and praying before going to sleep.

\subsection{Curiosity Character Education Value}

(2) Context: Nussa Asks Rara What 3S Stands For

Cat : Meow ... meow.

Rarra : ih ...eh.

Nussa : $3 \mathrm{~S}$ is an Indonesian culture which stands for smiling, salaam, greeting, umma what does this mean anyway?

Rarra : Don't you know? A smile is like this "hihi ...", greeting is like this "hello guys" hihi, and salaam is like this "assalamualaikum...".

(Data 2)

The fragment of speech (2) on (data 2) "3S is an Indonesian culture which stands for smiling, salaam, greeting, umma what does this mean anyway?" includes in the category of curiosity character education value. The character of nussa as a speaker shows his curiosity about $3 \mathrm{~S}$ as Indonesian culture. Curiosity character education value is a way of thinking to know something in depth. It can be proved that in the fragment of speech (data 2) through its context, nussa really wants to know something that is $3 \mathrm{~s}$ as Indonesian culture in depth. 


\subsection{Friendly/Communicative Character Education Value}

\section{(3) Context: Umma Explains Nussa About $3 \mathrm{~S}$}

Rarra : Then, if you already know, why do you ask me?

Umma : Hehe ... so, 3S stands for smiles, greetings, and salaam, this Indonesian hospitality culture is very good to be practiced every day. If we meet people on the street, we will smile then say hello or greeting. For example, assalamualaikum sir, good afternoon ma'am, excuse me miss, do you understand dear?

(Data 2)

The fragment of speech discourse (3) in (Data 2) "Hehe ... so, $3 S$ stands for smiles, greetings, and salaam, this Indonesian hospitality culture is very good to be practiced everyday. If we meet people on the street, we will smile then say hello or greeting. For example, assalamualaikum sir, good afternoon ma'am, excuse me miss, do you understand dear? includes friendly/communicative character education value. The fragment of speech (data 2) of the speech partner responds to questions from the speaker about the $3 \mathrm{~S}$ in Indonesian culture. This proves that the existence of education about the $3 \mathrm{~S}$ which is also related to social attitudes towards the environment.

\subsection{Social Care Character Education Value}

\section{(4) Context: Umma Asks Nussa To Accompany Rarra Sleeping}

Umma : Nussa, please accompany rarra! Remember what umma told to you before.

Nussa : Yes umma, why ra? I am sure that you forget to read the prayer before you go to sleep, with this (while taking a broomstick).

(Data 1)

The fragment of discourse (4) on (data 1) "Nussa, please accompany rarra! Remember what umma told to you before" includes in the category of social care character education value. The conversation shows an attitude of help and come to think of others or those around them who are more in need. It has been proved that umma helps to think of rarra who are afraid to sleep alone.

\subsection{Responsibility Character Education Value}

(5) Context: Umma Emphasizes on Nussa to Turn Off The Television

Nussa : Huh?

Umma : If you don't watch this television, please turn off, dear!

Nussa : Huhu.

Rarra : Nussa got hit, hihi.

(Data 4)

The fragment of speech discourse (5) in "If you don't watch this television, please turn off, dear!", the purpose of the speech (data 4) is that the speaker asks the speech partner to turn off the television if the television is not watched. This is proved that the character 
umma teaches nussa about responsibility. The piece of speech (data 4) includes in the category of responsibility character education value, in which the behavior of doing the actual task is carried out and having and thinking a consequence if you don't.

\section{Conclusion}

Character education value is an effort made by each individual in the formation of attitudes, which harmonize between social, environmental and cultural. This study has found the five-character education targets: (1) religious character education value, (2) curiosity character education value, (3) friendly/communicative character education value, (4) social care character education value, (5) responsibility character education value. Through the animation movie object of nussa and rarra, this study has revealed the purpose of the study, it was to find out the character education values.

\section{References}

Bendazzi, G. (2018). Twice The Fist Quirino Christiani and The Animated Feature Film. New York: CRC Press.

Cepi, R. (2015). The development of three-dimensional animation film for character education media in elementary school. E-Journal Upi.

Kenny Roy. (2014). Finish Your Film Tips and Tricks For Making an Animated Short in Maya. New York: Focal Press.

Koellhoffer, T. tara. (2009). Character Education: Being Fair and Honest. New York: Cheisea House Publishers.

Lickona, T. (2008). Pendidikan Karakter Panduan Lengkap Mendidik Siswa Menjadi Baik. New York: Educating for Character.

Mansur, M. (2011). Pendidikan Karakter: Menjawab Tantangan Krisis Multidimensional. Jakarta: Bumi Aksara.

Munir, A. (2010). Pendidikan Karakter Pengembangan Karakter Sejak dari Rumah. Yogyakarta: Bintang Pustaka Abadi.

Noddings, N. (2002). Education Moral People: A Craring Alternative to Character Education. New York: Teacher College Press.

Pikkov, U. (2010). Animasophy The Oretical Writings On The Animated Film. USA: Estonian Academy of Arts.

Suhadi, A. dan. (2018). Nilai Pendidikan Karakter pada Cerpen Wakasat Karya Wisran Hadi. Jounalof Language and Literature Education, 18(1).

Tridhonanto, A. (2014). Menjadikan Anak Berkarakter. Jakarta: PT. Gramedia. 